\title{
PROPOSAL TO CONSTRUCT THE OPERATIONAL BASE OF THE EDUCATIVE WORK PROCESS IN COLLECTIVE HEALTH ${ }^{1}$
}

\author{
Érica Gomes Pereira ${ }^{2}$ \\ Cássia Baldini Soares ${ }^{3}$ \\ Célia Maria Sivalli Campos ${ }^{3}$
}

Pereira EG, Soares CB, Campos SMS. Proposal to construct the operational base of the educative work process in collective health. Rev Latino-am Enfermagem 2007 novembro-dezembro; 15(6):1072-9.

This study aimed to construct the operational base of the educative work in health from a Marxist perspective. Reports of nursing experiences in the basic health services, published between 1988-2003, served as empirical base. The object was captured from: the participants; the action agents; the objective; health and education conceptions; and the generating necessity. The means/instruments were identified through: physical space; didactic resources; frequency of meetings; and the conception of health education. The type of evaluation; to whom it was directed; the goal to be reached and articulation between the theoretical and operational knowledge were identified in order to capture the purpose. The educative work in collective health can strengthen social groups when it becomes praxis that assumes the participant as a dialogical co-producer of the work in health.

DESCRIPTORS: health education; work; public health nursing

\section{PROPUESTA DE CONSTRUCCIÓN DE LA BASE OPERACIONAL DEL PROCESO DE TRABAJO EDUCATIVO EN SALUD COLECTIVA}

El presente estudio tuvo como objetivo construir la base operacional del trabajo educativo en salud a partir de la vertiente marxista. Los relatos de experiencia de enfermeras que laboraron en la red básica de servicios de salud, publicados entre 1988-2003, fueron utilizados como base empírica. El objetivo fue capturado a partir: de los sujetos, de los agentes de acción, del objetivo, de las concepciones de salud y de educación - saber hacer, y de la necesidad generadora. Los medios/instrumentos fueron identificados por medio: del espacio físico, de los recursos didácticos, de la frecuencia de sesiones, y de la concepción de educación en salud - saber operante. Para captar la finalidad se identificó: el tipo de evaluación, a quien fue dirigida, la meta a ser alcanzada, la articulación entre el saber hacer y el saber operante. El trabajo educativo en salud colectiva será un potencial de fortalecimiento para los grupos sociales cuando se constituya en una praxis que asume el sujeto como co-productor dialógico del trabajo en salud.

DESCRIPTORES: educación en salud; trabajo; enfermería en salud pública

\section{UMA PROPOSTA DE CONSTRUÇÃO DA BASE OPERACIONAL DO PROCESSO DE TRABALHO EDUCATIVO EM SAÚDE COLETIVA}

Este estudo buscou construir a base operacional do trabalho educativo em saúde, a partir da vertente marxista. Teve como base empírica os relatos de experiência da enfermagem na rede básica de serviços de saúde, publicados entre 1988 e 2003. O objeto foi capturado a partir dos sujeitos dos agentes da ação, do objetivo, das concepções de saúde e de educação - saber fazer; e da necessidade geradora. Os meios/ instrumentos foram identificados por meio do espaço físico, dos recursos didáticos, da freqüência dos encontros e da concepção de educação em saúde - saber operante. Para captar a finalidade identificou-se o tipo de avaliação, a quem foi dirigida, a meta a ser alcançada, a articulação do saber fazer e do saber operante. O trabalho educativo em saúde coletiva será um potencial de fortalecimento aos grupos sociais quando se constituir em uma práxis que assume o sujeito como co-produtor dialógico do trabalho em saúde.

DESCRITORES: educação em saúde, trabalho, enfermagem em saúde pública

${ }^{1}$ Study extracted from Master Thesis; ${ }^{2}$ RN, MS in Nursing, Laboratory Specialist, e-mail: egpereira@usp.br; ${ }^{3}$ RN, PhD Professor, e-mail: cassiaso@usp.br, celiasiv@usp.br. University of São Paulo, College of Nursing, Brazil. 


\section{INTRODUCTION}

This study addresses the construction of an operational basis for the educational work process in health based on the theoretical/methodological framework of Collective Health. The history of health education in Brazil has been based on the traditional theoretical-methodological framework of Public Health. However, as from the Sanitary Reform in the 70's, and with the constitution of the Collective Health field, it has been subject to influences from authors that recommend the emancipatory character of education ${ }^{(1)}$.

This work was developed based on the theoretical consideration that the health education process is a work process. That is, social health practices consist in work ${ }^{(2,3)}$. Under the Marxist analysis, health work is defined as a set of social practices and specific knowledge performed in their relationship with general social as well as with each of the instances integrating it ${ }^{(2)}$. This concept was used in healthcare to decode the elements constituting the health work process ${ }^{(3)}$.

Throughout Western Society history, until about two centuries ago, the objects of health work processes were represented by "entities". The only exception is one important period, and, therefore, when modern medicine revealed itself as a social practice, as from the late $18^{\text {th }}$ century, when it tended to seek its symbols in the classic Greece ${ }^{(3)}$. Hence, Hippocratic medicine performed a classification, through the observation of the set of natural changes causing suffering to man, calling this process clinical. The purpose of medical work started to be to imitate and favor nature to find the road to successful efforts, or to avoid failures, transforming an unsuccessful effort in its opposite. The act to recognize the type of present unbalance was called diagnosis, and knowing where the set of re-balance processes was heading to was referred to as prognosis ${ }^{(3)}$.

This structure, acknowledged as such, legitimated medical work, and, subsequently, it was the center of healthcare service production. Focusing on disease and the subject's disease, it completed the specialized literature and, consequently, the healthcare intervention practices.

Some scholars confronted this concept, assuming that the health-disease process assumes heterogeneous characteristics, according to the role each social group takes on in the production of material life, and relates to the other social groups ${ }^{(4)}$. For this reason, the social character of the health-disease process is empirically manifested more clearly in the group than in the subject. Considering the collective health-disease process, it is important to know how the biological process occurs socially, so as to reacquire the unit between disease and health, dichotomized in clinical medical thinking. In society, the prevalent mode of living is the biological mode, perceived as a collective process, which, in turn, expresses characteristic biological disorders - the disease. Both are inseparable: they occur as points in time of a single process; nevertheless, they can be distinguished ${ }^{(5)}$.

These formulations comprise the original base of Collective Health in Latin America, as of the 1980s. Different from traditional Public Health, this field considers health-disease as a historical and dialectic process. "Conventional public health conceptualizes health-disease empirically, reducing it to the phenomenon and individualized level of the etiological causality, whereas collective health establishes up the historical determination of the collective production process of health-disease states. While public health welcomes the empirical-analytic (functional structuralist), Popperian and phenomenological methods, collective health incorporates the dialectic materialist method." ${ }^{(6)}$.

Thus, the social determination model of the health-disease process "proposes that, given a certain production mode, there is a social reproduction process that establishes a certain social formation. This formation determines the existence of a structure of social classes and their relationships. The class dynamics implies a unitary relationship between production and consumption; in this dialectic relation, production does not occur in the absence of consumption, and consumption depends on production. The collective bio-psychosocial process in different social classes is determined by means of production and consumption processes. Regarding production, the insertion of social agents in concrete work processes determines not only their own exposure to specific occupational risks as well as their access to the produced wealth, through its yields. In turn, these yields determine consumption levels, and, therefore, the access to material goods of life including, but not limited to food, housing, sanitation, medical care, education, etc. Therefore, through the dialectic relation between production and consumption, it is possible to understand health differentials among and within social groups"(7).

The Collective Health conceptual framework "permits an understandably provisional delimitation 
in this scientific field, as a knowledge field and practice scope ${ }^{\prime(8)}$. As a knowledge field, Collective Health proposes "to study the health/disease phenomenon in populations, as a social process; to investigate the production and distribution of diseases in society, as production and social reproduction processes; to analyze health practices (work process) in their articulation with the other social practices; and, finally, it aims to understand how society identifies health needs and problems, seeking their explanation, and becoming organized to face them ${ }^{\prime(8)}$. In addition, as a scope of practices, Collective Health "involves certain practices that have social health needs as their object, and different knowledge, disciplines, material and non-material technologies as work instruments, as well as social group- and environment-centered intervention as their activities, regardless of the professional category and institutionalization model"(8).

In Collective Health, the basic health unit is conceived as an entrance door to the healthcare system, and must meet a set of health needs with practices that go beyond the individual healing dimension ${ }^{(9)}$. In this sense, health education is responsible for the transformation of unfelt needs into recognized needs, both by the population and by workers responding to healthcare in the scope of the basic unit ${ }^{(6)}$.

\section{THE HEALTH EDUCATION WORK PROCESS}

This study emphasizes the discussion about education as a part that cannot be dissociated from the production relationships, as it permeates workers' activity, considering that they somehow use specific technical knowledge when interfering in the world, changing nature and transforming along this process. Education can be understood as the appropriation of historically produced knowledge. It is the resource societies use to preserve their culture, passing from generation to generation and guaranteeing the perpetuation of its historical character ${ }^{(10)}$.

The reproduction of historically produced knowledge through education is not restricted to the immediate and complete act of consumption. In this act, learners get hold of a knowledge that becomes incorporated into their being, and that extends beyond the production act, throughout the subject's life. In this sense, learners do not appear solely as product consumers, but also as objects and producers of the educational practice ${ }^{(10)}$.
Inspired by assumptions from the field of education $^{(10)}$ applied to health education, it can be affirmed that healthcare service users are not mere consumers of a given individual or group advice; rather, they also work in the ongoing educational process, aiming to achieve an educational purpose, and, thus, show their co-production with the other people actively involved in the educational process. Hence, the participation of healthcare service users in the educational activity appears not only as an object, but also as a subject.

In the problematizing practice of reality, subjects develop the ability to identify and understand the world presented to them, in their relations with it, no longer as a static reality, but as a reality under transformation. By becoming more aware of the situation, men get hold of it as a historical reality, for this same reason, capable of being transformed ${ }^{(11)}$.

According to Saviani ${ }^{(12)}$, who proposes a historical-critical reading of education, the starting point to understand reality is to contextualize the social practice that is common for both the agent and the subject of the educational activity, each one bringing different experiences and knowledge. The next step in the educational process is problem-solving and identification of the main themes that need to be solved in the social practice scope and, consequently, the definition of the knowledge that must be detained. The third step addresses the theoretical and practical instrumentalization required for subjects involved in the educational activity to recognize and understand the problems detected in social practice by means of the culturally available tools. The fourth step is to build a new form of understanding social practice, reached through the incorporation of cultural instruments, now transformed into active elements of social transformation. Finally, the fifth step constitutes the social practice per se.

Based on the assumption that healthcare service production objects are the profiles of social representation and health-disease, evidenced in the geo-social territory, and that the purpose is their transformation, with a view to the general improvement of health-disease processes, the work of different social practices corresponds to the work processes required for that production. Health education is inserted as an instrument, for example, of the healthcare work process, with a view to creating concrete possibilities for the population to participate as active co-producing historical subjects of the transformation of its profiles ${ }^{(13)}$. 
In this sense, the health education action is inter-dependent on the educational background of each worker, on the experienced historical context, and on the institution where this practice is established ${ }^{(1,10)}$.

\section{THE CONSTRUCTION OF THE OPERATIONAL BASIS}

The object of the health education work process

The work object is not delimited by itself, it is delimited by the look from a subject who foresees a potential outcome in a certain fragment of nature, drafted in a subjective project. The process of evidencing something in nature as an object of transformation to meet the needs results from the presence of a subject. If the subject self-transforms while reproducing at the cost of transformations in nature, both will become historical ${ }^{(3)}$. Health education work has human praxis as its object, which is understood as articulation between thought and action and possibility of transposing daily reality starting from itself ${ }^{(14)}$. Thus, education work per se, which may be planned and performed "by the group of healthcare workers guided by a project that articulates clinical work and epidemiology, from the perspective of social thinking in health, in its articulation, produces the transformation of the object"1(13).

In conclusion, human praxis is the object of collective health education work. Moreover, it is part of the construction process of the object of health care service and collective health practice production. In other words, it refers to the articulation between action on material life and reflection on everyday work practice. Therefore, there are different praxis levels, which vary according to the degree of penetration of the active subject's awareness in the practical process and with the degree of creation or humanization of the transformed matter, evidenced in the product of its practical activity ${ }^{(15)}$.

In the expression of their education work object, collective health workers possess knowledge about some aspect of social reality and health to be transformed, which is shown in healthcare service users. However, while the material work object opposes its passive transformation, users' response "takes place according to their human specificity, which is at the same time natural and a natural transcendence. Therefore, it is an active participation, as a historical being ${ }^{\prime \prime}(10)$.

Therefore, it is concluded that the education work object in Collective Health will only reach the human praxis when workers assume users as objects and co-producers of their work, since "in a legitimate educational process, the educated being is not only present, but also participates in the developed activities. The need for active student participation itself is only present because education assumes a change in the nature of its object" ${ }^{\prime \prime}(10)$.

The specificity of the education work assumes that the knowledge involved in the education process cannot be expropriated from the agent of the educational activity, under the risk of decharacterizing the educational process itself, since it is the worker who performs the work ${ }^{(10)}$. In case the worker believes that the user is merely the object of his/her work, the activity will not strengthen his/her active participation as a co-producing subject in the educational activity. As the object, s/he will be the product consumer at the moment of its production, and, as a subject, bearer of a certain knowledge - raw material of the process, which will grant substance and content to the educatorlearner relationship ${ }^{(10)}$.

Therefore, collective health workers' knowledge about the education work object will be scrutinized by their concept of health and education. This knowledge, which identifies what will be the education work object from nature, subjects' operating/instrumental* knowledge; for example, the health education concept in the next constituting steps of the health education work process.

Means and instruments of the health education work process

The work instruments correspond to how the operating/instrumental knowledge, material resources and work strength, which constitute the concrete work - which only transforms into abstract work by means of exchange as a social form of production - are incorporated in the work process and synthesize in a "product a usage value, a material from nature adapted to human needs by means of changes in its form" ${ }^{\prime \prime}$.

The working means direct the synthesis of the object's quality/utility and the project of the purpose, in the sense that "they are a thing or a set

* Know-how is the knowledge that articulates all constitutive elements of pedagogical work and the knowledge that is transmitted is what equips the transformation of the theme for the subjects of the pedagogical work process ${ }^{(10)}$. 
of things the worker inserts between himself/herself and the work object, and serve to direct his/her activities upon this object. Moreover, they measure the development of human work force and indicate the social conditions the work is performed in"(16).

By integrating the education work process, the instruments correspond to the dead work incorporated into the object to reach the purpose - product of the work process. In addition, it should be reminded that, this way, the work instruments will not guarantee the good performance of the work process. The continuity of the instrument consumption process for the transformation of the object will depend on how this same object is extracted, as it will be the healthcare worker's living work oriented to the extract of nature where the working object is seen, which provides the guidelines for using the work instruments ${ }^{(3,16)}$. Therefore, something will only become a work instrument when the subject with a project uses it, but only if its qualities and use to transform the object are valued while using $i \mathrm{t}^{(3)}$.

When the worker indiscriminately presumes the work instruments without considering the extract of nature to be transformed - work object - the instruments are not used in their full potential. Therefore, workers "become living complements of a dead mechanism that will exist independently"(16).

The purpose of the health education work process

The human work activity is related to a purpose always present before and after the work process. At the end of the work process, a result, which already existed - subjectively - in the worker's imagination, appears. "The worker not only transforms the material s/he operates; s/he imprints the project $s /$ he consciously aimed for in the material, which constitutes the determining law of the worker's mode to operate and which his/her will is subject to" ${ }^{\prime 16)}$.

The purpose of Collective Health education work depends on the object to be transformed and, as the latter depends on the health and education concept, the purpose of the health service production process will be to transform social reproduction and health-disease profiles in homogeneous social groups (work object), with a view to improving collective health-disease processes ${ }^{(13)}$.

Taking this into consideration, in order to improve collective epidemiological profiles, users should participate in the acknowledgement of its forms of social reproduction, distress and strengthening potentials they are exposed to, as well as the distress and strengthening manifestations evidenced throughout their lives. This participation will occur as the educational activities with the users facilitate obtaining information and knowledge that will guarantee their autonomy, so as to cope with the distress potentials as well as improve the strengthening potentials materialized in their health-disease processes ${ }^{(13)}$.

Assuming that the Collective Health education work process is oriented by the purpose of improving collective epidemiological profiles, this study sought to build an operational basis to permit the development of the educational work processes.

Identification of the health-education process elements: empirical base (Figure 1)

Based on this theoretical-methodological framework, the study sought the specific characteristics of the educational work process required to identify the object, means, instruments and working purpose. The empirical basis used in this study to support the identification of work process elements was a literature review on the experience reports of Brazilian nurses working in the basic healthcare service network, published between 1988 and 2003, used as the empirical basis ${ }^{(17)}$.

The work object was found through the description of the agents involved in planning and performing educational actions; health and education concepts comprising the agents' know-how; the described objectives; the target-subjects of the education action; and the action-generating need:

Regarding agents: indicator of service and university workers involved in planning and performing actions - qualifies the agent's strength and the institutional nature it belongs to, in order to transform the object-subject of the educational activity. In addition, it permits comparing agents planning the activity with those performing it, in order to identify the technical division of nursing education work in the basic healthcare network. Assuming that agents refer to those in a position to identify and decode the health reality, an object to be transformed by healthcare work, the need-generating index was chosen to evaluate if the educational process reported by the agents is the nursing care or teaching work process instrument; and the education concept index and the health concept index - which discerns the agent's strength to consider the nature, delineate the work object, and trace the transformation process of the object-subject by means of know-how, based on a theoretical reference framework orienting his educational work. 
Regarding the purpose: Theme indicator - the purpose to be addressed with the educational activity subjects, indicating the praxis (way to think and act) the agent considers necessary to transform.

Regarding the subject: indicator of the subjects' empirical qualification - permitted to qualify if the agents identify the subjects: by means of the cycle of life they are in; by the cycle of life they are in and their social network; by the quality of being an institution user; by the cycle of life they are in, gender, and the quality of being an institution user; and by the condition they live in at the moment of the educational activity. Indicator of participation in theme planning - permits to evaluate if the subjects representing the population participate as co-producers of the needs considered by the agent as transformable in an educational process. The presence of the subjects in the theme excerpt to be addressed in the educational action favors the sharing of the object that is to be transformed. Indicator of the scope of action permits to evaluate if the object is individual or collective, which may be defined as a group of subjects or as a common group, of the same class or condition.

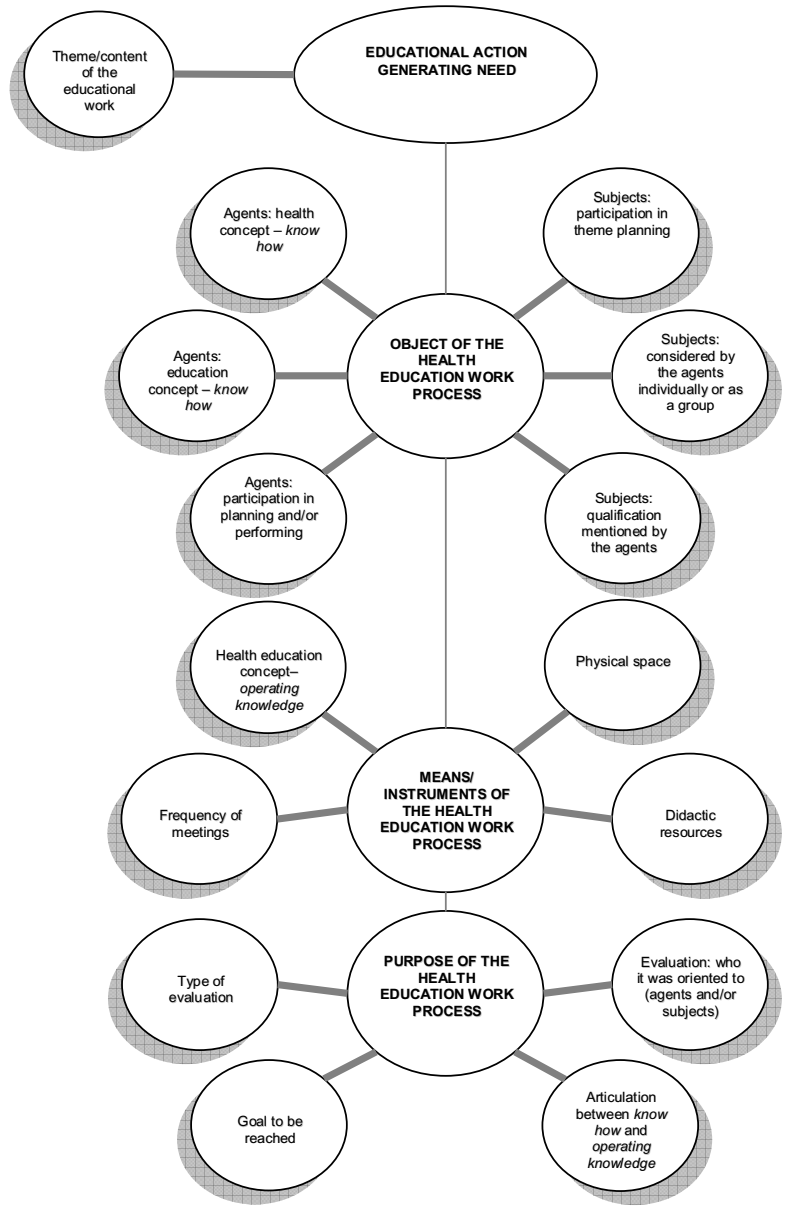

Figure 1 - Elements constituting the health education work process ${ }^{(17)}$
The work means and instruments were identified by: Physical space indicator, where the agent establishes the educational work process, considering that the place where the educational process is performed is not always the environment the agent works in everyday. Didactic resource indicator, which evaluates the feasibility of concrete object-subject transformation in the educational process and points to a reiterative or transforming praxis. Frequency indicator of the meetings, reflecting the steps required in the educational process. The operating/instrumental knowledge was evaluated by means of the health education concept indicator, which permits seeing the agent's strength to use a theoretical reference, which increases the chance of reaching the goals proposed for the educational work.

In order to identify the elements related to the purpose of the educational work process, the following were used: Evaluation presence indicator, to show if there was a concern with perceiving some transformation level of the object; Evaluation type indicator, to prove if there was a concern with identifying successive transformations during the process (evaluation of the teaching-learning process) and/or if the educational work process purpose was identified only at the final moment of the process or at other moments (evaluation of the short-, medium-, and long-term results); Indicator of the goal to be reached, regarding: adopting healthy behavior, discussing health problem causes, preventing a certain disease or, controlling a certain disease or problem; promoting the improvement of living conditions at home, in the neighborhood or in another space associated with the consumption scope; promoting better work conditions. Know how and operating knowledge articulation indicator, in order to identify indexes of articulation between the knowledge constituting the know how - education and health concept - to identify the work object, and the operating knowledge - health education concept - which is part of the health-education work process instruments. Indicator of evaluated individuals: identified who underwent evaluation, either the subject and/or agent of the educational process.

\section{CONCLUSIONS}

These indicators made it possible to identify a variety of objects, means/instruments and purposes 
of the work performed especially by nursing professionals in the basic healthcare service network as of 1988 . These results ${ }^{(17)}$ showed a divergence with the theoretical-methodological and operational axis of Collective Health. Many times, they are distant from traditional public health, but without any coherence between the categories composing the Collective Health educational work process. The educational work process is closer to the molds of a public health system that incoherently supports the participation instrument - including authors like Paulo Freire - only to legitimate technical knowledge, and makes the so-called community responsible to search solutions for their health problems.

The Brazilian society composes educational works in the basic health service network, whose development represses the possibilities of the generic person to use creativity and freedom, because it focuses on specific objects taken from a world view that regards man as an individual being, working as a system of organs in perfect harmony, which is part of a homogeneous society, with no social classes, a functionalist view ${ }^{(2)}$.

To develop a Collective Health educational process, first, there is a need to articulate the health concepts grounding the constitution of the object with those of education, which will coherently support the transformation of this object. Second, it is necessary to understand educational practice as a work process. The bases of these concepts are Marxist, which means considering health as a socially determined process $^{(5)}$ and education from an emancipatory point of view, as a historical-critical process of understanding reality, a locus where educator and learner interact ${ }^{(10-12)}$. Similarly, in order to develop a Collective Health educational process, the health education concept used in the transformation of a specific theme, with a delimited group, should be coherent with the health and education concepts grounding the Collective Health field: education that provides social groups with instruments to search for the roots of the health disease process and constitute collective solutions.

Correspondingly, the purposes of the educational process will be reached through the choice of instruments that intensify the possibility of problem-solving, predicting a place that favors the dialogical relations and attenuates the institutional hierarchy. The educational instruments must incorporate steps that allow the usual "coming-andgoing" involved in the reflection process.

The purpose is determined by transforming this object, providing health workers and social groups with instruments to face the distress potentials, and constituting historical subjects capable of making use of what is socially produced. The only form to verify if this purpose is being reached is by means of evaluation processes, which are commonly neglected. Evaluations must address the educational process as a whole. Therefore, in addition to result indicators, it must also predict process-evaluation indicators. Educational processes in the Collective Health perspective allow agents and subjects to participate as co-producers of the process, from planning to evaluation.

\section{REFERENCES}

1. Merhy E. Saúde e movimento popular: o relato de uma experiência. In: Pino IR, (organizador) Cadernos do Cedes Centro de estudos Educação e Sociedade 1987. São Paulo (SP): Cortez; 1987. p.44-53.

2.García JC. Medicina e sociedade: as correntes de pensamento no campo da saúde. In: Nunes ED, (organizador) Medicina social: aspectos históricos e teóricos. São Paulo (SP): Global; 1983. p.95-132.

3. Mendes-Gonçalves RB. Práticas de saúde: processos de trabalho e necessidades. São Paulo (SP): CEFOR; 1992.

4. Laurell AC, Noriega M. Processo de produção e saúde: trabalho e desgaste operário. São Paulo (SP): Hucitet; 1989. 5. Laurell AC. A saúde doença como processo social. In: Nunes ED, (organizador) Medicina social: aspectos históricos e teóricos. São Paulo (SP): Global; 1983. p. 133-58.

6. Breilh J. Nuevos conceptos y técnicas de investigación: guía pedagógica para un taller de metodología (epidemiologia del trabajo). Ecuador: Centro de estudios y asesoría en salud; 1995.
7. Victora CG, Facchini LA, Barros FC, Lombardi C. Pobreza e saúde: como medir nível sócio-econômico em estudos epidemiológicos de saúde infantil? [Livro resumo] In: Anais do 10 Congresso Brasileiro de Epidemiologia 1990; Campinas (SP): Abrasco; 1990.

8. Paim JS, Almeida Filho N. Saúde coletiva: uma "nova saúde pública" ou campo aberto a novos paradigmas?. Rev Saúde Pública 1998; 32(4):299-316.

9. Schraiber LB, Mendes-Gonçalves RB. Necessidades de saúde e atenção primária. In: Schraiber LB, Nemes MIB, Mendes-Gonçalves RB. (organizador) Saúde do adulto: programas e ações na unidade básica. São Paulo (SP): Hucitet-Abrasco; 2000. p. 29-47.

10. Paro VH. Gestão democrática da escola pública. São Paulo (SP): Ática; 2002.

11. Freire P. Pedagogia do oprimido. Rio de Janeiro (RJ): Paz e Terra; 2002.

12. Saviani D. Escola e democracia: teorias da educação, curvatura da vara, onze teses sobre a educação política. Campinas (SP): Autores associados; 2003. 
13. Queiroz VM, Salum MJL. Reconstruindo a intervenção de enfermagem em saúde coletiva. [livro resumo] In: Anais do $48^{\circ}$ Congresso Brasileiro de Enfermagem; 1996; São Paulo (SP): ABen/SP; 1996.

14. Gonzaga FRSR. Para além do cotidiano: reflexões acerca do processo de trabalho de educação em saúde. [dissertação] Florianópolis (SC): Centro de Ciências da Saúde/UFSC; 1992. 15. Vázquez AS. Filosofia da práxis. Rio de Janeiro (RJ): Paz e Terra; 1986.

16. Marx K. O capital: crítica da economia política. Livro 1: O processo de produção capitalista. Rio de Janeiro (RJ): Civilização Brasileira; 1968. p. 201-23.

17. Pereira EG. A participação da enfermagem no trabalho educativo em saúde coletiva: um estudo dos relatos de experiência produzidos por enfermeiros brasileiros no período 1988-2003. [dissertação]. São Paulo (SP): Escola de Enfermagem/USP, 2005. 